\title{
Roads Impact Tree and Shrub Productivity in Adjacent Boreal Peatlands
}

\author{
Saraswati Saraswati ${ }^{1,2, *}$, Yubraj Bhusal ${ }^{2}$, Andrew J. Trant ${ }^{3}$ and Maria Strack ${ }^{2}$ \\ 1 Department of Earth and Environmental Sciences, University of Waterloo, 200 University Ave. W., \\ Waterloo, ON N2L 3G1, Canada \\ 2 Department of Geography and Environmental Management, University of Waterloo, 200 University Ave. W., \\ Waterloo, ON N2L 3G1, Canada; yuba.bhusal@gmail.com (Y.B.); mstrack@uwaterloo.ca (M.S.) \\ 3 School of Environment, Resources and Sustainability, University of Waterloo, 200 University Ave. W., \\ Waterloo, ON N2L 3G1, Canada; atrant@uwaterloo.ca \\ * Correspondence: xsaraswa@uwaterloo.ca
}

Received: 17 April 2020; Accepted: 20 May 2020; Published: 24 May 2020

check for updates

\begin{abstract}
Peatlands in the western boreal plains of Canada are important ecosystems as they store over two percent of global terrestrial carbon. However, in recent decades, many of these peatlands have been fragmented by access roads constructed for resource extraction and transportation, challenging their carbon storage potential. To investigate how roads have been impacting tree and shrub growth and productivity in these peatlands, this study was conducted in a forested bog and woody fen in Carmon Creek, Alberta, Canada. In 2017, vegetation surveys were conducted along $20 \mathrm{~m}$ transects that extended on both sides of the road with $4 \mathrm{~m}^{2}$ circular plots at 2, 6 and $20 \mathrm{~m}$ distance from the road and were followed by disc or core collection from woody stems. Within $20 \mathrm{~m}$ of the road at the bog site, we observed a shift towards significantly larger radial growth of trees in the downstream areas $(t=3.23, p=0.006)$ where water table position was deeper, while at the fen site, radial growth of tall shrubs had little response to the road. Combining the effects of direct tree clearing and hydrology induced shifts in growth, aboveground net primary productivity (NPPag) post-road construction was reduced significantly in areas where vegetation was cleared during the road construction (i.e., upstream areas of the bog: $t=5.21, p<0.0001$ and downstream areas of the fen: $t=2.64, p=0.07)$. Substantially lower NPPag around the road construction areas compared to reference areas shows tremendous loss of carbon sink potential of trees and shrubs after road construction through peatlands. Altogether, roads constructed through peatlands perpendicular to the water flow may shift long-term carbon sinks into sources of carbon, at least for the initial few years following road construction.
\end{abstract}

Keywords: boreal wooded peatlands; resource access roads; tree productivity; dendrochronology

\section{Introduction}

The western boreal plains (WBP) region of Canada plays an important role in maintaining global carbon soil stocks as it comprises $50 \%$ wetlands, over $90 \%$ of which are peatlands, and these peatlands store approximately $2.1 \%$ of global terrestrial carbon [1]. In the WBP, the aboveground carbon storage ranges from 200 to $900 \mathrm{~g} \mathrm{~m}^{-2}$ [1,2] because the short growing season (e.g., May to August; [3]) and frozen soil for over half of the year slows decomposition, allowing for more storage. The primary productivity of the WBP wetlands varies between and within peatland types (bogs and fens) and is controlled by the vegetation type, water table depth (WT) and soil properties, including temperature, $\mathrm{pH}$, electrical conductivity (EC) and nutrient availability [4-6]. In general, wooded bogs and fens contain greater aboveground biomass compared to shrubby and open peatlands $[1,7]$. 
However, the local biogeochemical properties and micro-climate bring annual variations in overstory productivity in peatlands. On average, approximately $2 \%-16 \%$ of the annual net primary productivity (NPP) is stored as peat in peatlands [8] due to the low rates of organic matter decomposition [1,9-11].

The variability of the WT has been linked to distinctive vegetation types, NPP rate and ecosystem functions in peatlands [12-18]. Natural variability due to peatland microtopography results in vegetation gradients [17,19-21], with greater shrub biomass on hummocks and increases in graminoids in wet conditions [18,22]. Long-term drainage or deeper WT position resulting from drought or land-use change has been linked to growth enhancement of tall shrubs and trees in several fens of the boreal region [23]. Drainage studies in WBP wooded bogs illustrate that both shrub and tree biomass and NPP increase under drier conditions, while the cover of Sphagnum mosses is reduced [17].

Similarly, various anthropogenic disturbances, including deforestation and forest degradation caused by land-use changes and logging, infrastructure development and petroleum oil production and exploration [24-31], have altered the rate of primary productivity in WBP wetlands [30]. Over the last several decades, as a result of anthropogenic disturbances, a road network over $217,000 \mathrm{~km}$ in length has been constructed in boreal regions of Canada with many roads passing through WBP peatlands [32]. The construction of roads initially involves vegetation removal and conversion of peatland to a completely new land-use system (i.e., the road). The roads often act as dams, both due to compaction of peat below the road and the placement of material used to build the structure of the road itself $[3,33]$. In the long-term, it is evident that the upstream side of the road will experience flooding $[30,33,34]$, resulting in significant mortality of pre-disturbance vegetation. For example, black spruce and larch, the dominant tree species found in WBP peatlands, have shallow roots to access oxic parts of the soil profile. However, long-term flooding is responsible for tree dieback [23,30]. The downstream side of the road can potentially support new vegetation types and increased woody vegetation growth as the WT remains mostly deeper below the surface [23,34].

Despite these expected shifts in overstory productivity, few studies have comprehensively documented the magnitude and direction of the impacts on the growth of peatland trees and shrubs related to roads. To fill this gap, we investigated annual radial growth and aboveground NPP (NPPag) of the dominant woody species in two peatlands crossed by resource access roads in northern Alberta, Canada. We hypothesized that:

1. On the upstream side of the road, the annual radial growth of trees and tall shrubs would be significantly less than the downstream side of the road.

2. The NPPag of trees and tall shrubs would be significantly reduced by vegetation clearing during road construction.

3. The greatest impact of the road would be observed closest to the road where hydrologic impacts and clearing of vegetation have been observed to be most severe.

\section{Materials and Methods}

\subsection{Study Sites}

The study was conducted in a wooded bog $\left(56^{\circ} 21^{\prime} 44^{\prime \prime} \mathrm{N}\right.$ and $\left.116^{\circ} 47^{\prime} 45^{\prime \prime} \mathrm{W}\right)$ and a shrubby fen (56 $22^{\prime} 09^{\prime \prime} \mathrm{N}$ and $116^{\circ} 46^{\prime} 12^{\prime \prime} \mathrm{W}$ ) located in the WBP of Canada (Figure 1, for details, see: [21,25]). The growing season (May to August) weather data (2008-2017) recorded at the Peace River Airport Station had a mean daily maximum temperature ( \pm standard error) and mean seasonal total rainfall of $21.3 \pm 0.8^{\circ} \mathrm{C}$ and $206.1 \pm 28.4 \mathrm{~mm}$, respectively [35]. The mean growing season WT position (measured across both 2016 and 2017) was $15.2 \pm 2.5 \mathrm{~cm}$ and $10.9 \pm 2.9 \mathrm{~cm}$ below the surface in the bog and fen, respectively [36]. At the bog site, the flow direction was perpendicular to the road. However, at the fen site, the flow direction was nearly parallel to the direction of the road [3]. Overstory vegetation at the bog site was dominated by black spruce (Picea mariana) with an understory of shrubs, including Labrador tea (Rhododendron groenlandicum), bog cranberry (Vaccinium oxycoccos) 
and ligonberry (V. vitis-idaea). In the fen, willow (Salix spp.), alder (Alnus spp.) and paper birch (Betula papyrifera) dominated the overstory.

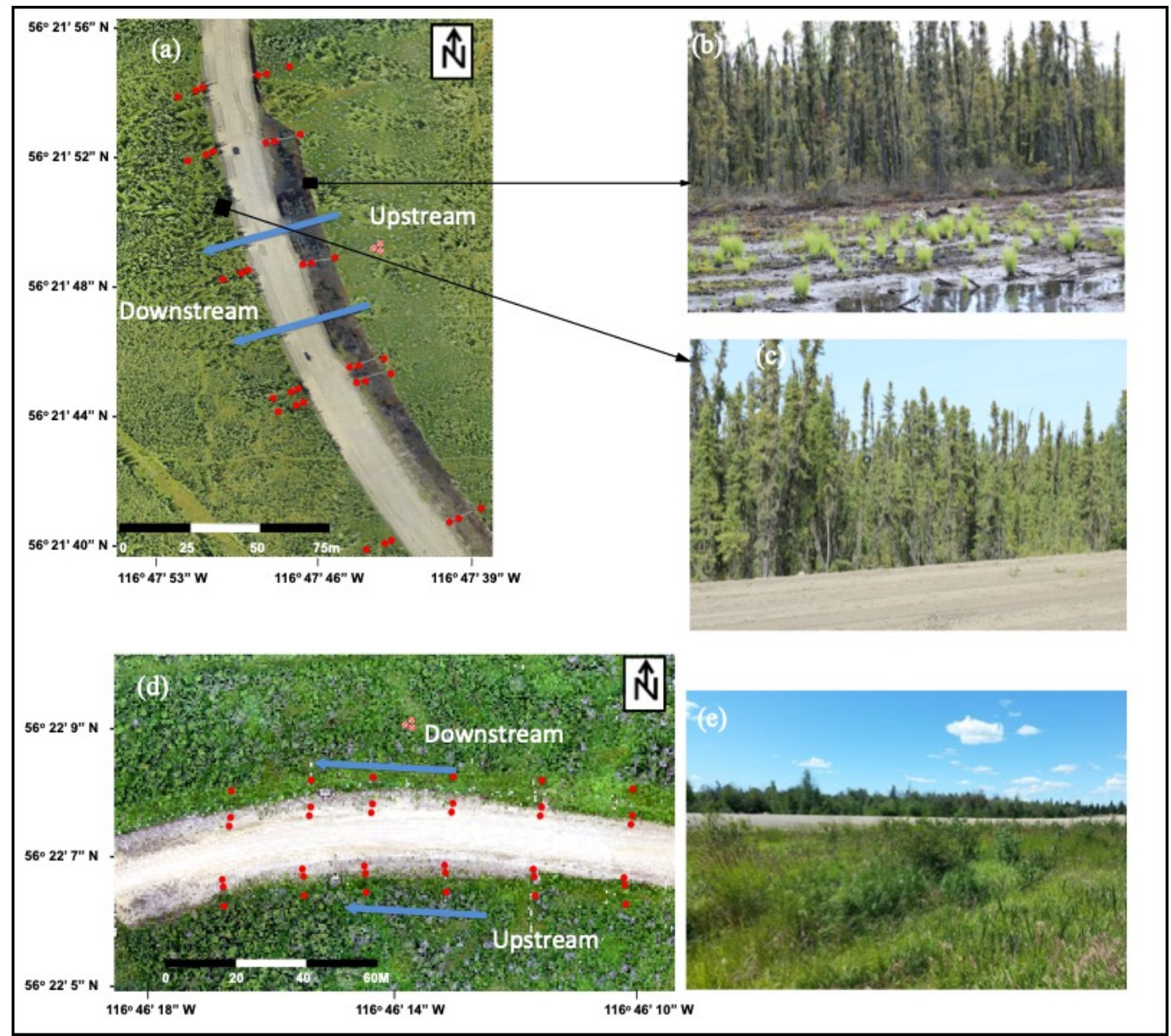

Figure 1. (a) Bog site aerial view taken in 2016, (b) bog upstream side of the road close up view, (c) bog downstream side of the road close up view, (d) fen site aerial view taken in 2015 and (e) fen site looking into upstream from the downstream site. Red circles represent the location of sample plots along the transects, circles with pattern fill are reference site plots, and arrowheads inside maps show flow direction after road construction.

The resource-access roads bisecting the fen and bog were constructed in 2013 and 2014, respectively, by first removing vegetation and then placing glacial tills as fill material on the geotextile layer over the compressed native material, which is peat (for details, see [3]). In addition, to improve the visibility, the vegetation was cleared in areas up to $18 \mathrm{~m}$ from the edge of the road for the majority of the upstream side (east) of the bog (except on one transect) and downstream side (north) of the fen during road construction.

\subsection{Study Design and Data Collection}

Six transects perpendicular to the road, extending to $20 \mathrm{~m}$ on both sides of the road, were established at the bog and fen study sites. At both sites, along these transects, $4 \mathrm{~m}^{2}$ circular sampling plots (radius of $1.13 \mathrm{~m}$ ) were established at 2, 6 and $20 \mathrm{~m}$ from the road edge on both sides of the road (upstream and downstream, Figure $1 \mathrm{a}, \mathrm{d}$ ) to conduct surveys of trees and tall shrubs (i.e., shrubs taller than $50 \mathrm{~cm}$ ) to obtain overstory NPPag. Additionally, triplicate plots (randomly laid at least $4 \mathrm{~m}$ apart) at approximately $50 \mathrm{~m}$ from the road edge were established as reference plots in each study site. The position of reference plots at $50 \mathrm{~m}$ from the road was determined as appropriate by vegetation 
composition and satellite imagery, as explained in [36]. Overall, we established a total of 39 plots in each study site. Within each plot, all trees were measured for total height and basal diameter (BD, to the nearest millimeter, measured immediately above the butt swell). In the fen, shrub height and BD of stems within the plots were measured for tall shrubs.

Tree measurements within plots were followed by stem disc (from trees with $<5 \mathrm{~cm} \mathrm{BD}$ and height $<1.3 \mathrm{~m}$ ) or increment core (from trees with $>5 \mathrm{~cm} \mathrm{BD}$ and height $>1.3 \mathrm{~m}$ ) collection from selected trees located at 2, 6 and $20 \mathrm{~m}$ from the road. Trees (which included both saplings and trees) for stem disc or core collection were selected to represent all BD classes $(<1,1-3$ and $>3 \mathrm{~cm}$, which were obtained from the plot vegetation measurements) at respective distances on both sides of the road. While a minimum of 10 stem discs or cores were collected from reference area plots, a minimum of four trees at each 2, 6 and $20 \mathrm{~m}$ distance on both sides of the road were collected for each transect. In addition to $\mathrm{BD}$, tree species, diameter at breast height and total height were recorded from the corresponding trees before collecting stem discs or cores. The base and top parts of each disc were marked before bagging samples. For the fen, for each species within the plots, height, total shrub width, number of stems and BD of stems (at $5 \mathrm{~cm}$ from the surface) were measured. Stem discs from the thickest and tallest 5 stems from each plant/multi-stemmed shrub present at each distance for the road were collected. Tree cores were extracted with an increment borer (Haglof Increment Borer), and collected cores were stored in separate paper straws.

In 2016, a total of 39 water wells (PVC tubes of 1 to $1.5 \mathrm{~m}$ deep) were installed in each study site representing each sampling plot. During summers (May to August) of 2016 and 2017, the WT depth relative to the ground surface was measured every other week.

\subsection{Ring Width Processing and Biomass Estimation}

In the laboratory, tree cores were glued in grooves of lumber frames $(60 \times 10 \mathrm{~cm})$, and both tree discs and cores were manually sanded with sandpaper (80 to 400 grit). Ring widths for the previous 10 years (2008 to 2017) were measured using a Velmex sliding stage micrometer (precision $0.001 \mathrm{~mm}$ ) dissecting microscope and MeasureJ2x software (VoorTech Consulting, Holderness, NH, USA). Sampled trees in the bog were relatively older than tall shrubs in the fen, where approximately $60 \%$ of those sampled were less than four years old. We attempted to visually and statistically cross-date samples though the samples were only processed for the period of interest (i.e., most recent 10 years), making this challenging. For each chronology, we recorded the sample depth, mean ring size (mm) and the inter-series correlation (Table S1). Statistically, analyses for ring width chronologies were performed in program $\mathrm{R}$ [37] using package 'dplR' [38-40].

\subsection{Annual NPPag Estimation}

The total aboveground biomass of black spruce was estimated by Equation (1), developed by Bond-Lamberty et al. [41]. Meanwhile, the aboveground biomass of tall shrubs and trees found in the fen site (e.g., bog birch, willow and alder) were determined by allometric Equations (2) developed by He et al. [42]:

$$
\begin{gathered}
\log _{10} \mathrm{Y}=\mathrm{a}+\mathrm{b}\left(\log _{10}(\mathrm{BD})\right) \\
\mathrm{Y}=\mathrm{aBD} \mathrm{b}^{\mathrm{b}}
\end{gathered}
$$

where $\mathrm{Y}$ is aboveground biomass $(\mathrm{g}), \mathrm{BD}$ is the basal diameter $(\mathrm{cm})$, a and $\mathrm{b}$ are the coefficients specific to each species (Table 1 ).

The BD of each tree/stem for the year 2016 (i.e., the previous year) was estimated by subtracting twice the mean per species width of the outermost radii (2017 mean tree ring width of the respective tree species) from the respective field measured BD. This 2016 BD was used to calculate the biomass in 2016 using, respectively, Equation (1) or (2), and then, the difference in biomass between the years was computed. This was followed by the annual NPPag estimation as the difference between calculated biomass and biomass at the end of the previous growth year for each species. 
Table 1. Constants for the allometric Equations used in the study.

\begin{tabular}{cccc}
\hline Species & $\mathbf{a}$ & $\mathbf{b}$ & Logarithmic Correction Factor $^{2}$ \\
\hline Black spruce $^{1}$ & 1.743 & 2.401 & 1.094 \\
\hline Birch $^{2}$ & 49.52 & 2.027 & - \\
Willow $^{2}$ & 55.85 & 2.325 & \\
Alder $^{2}$ & 44.06 & 2.395 & \\
\hline From the allometric equations developed by Bond-Lamberty et al. [41] and ${ }^{2}$ by He et al. [42].
\end{tabular}

To calculate NPPag per plot, first, from the 2017 survey of trees and tall shrubs from plots located at transects, we determined the conversion factors for each species per plot (i.e., tree basal area per area of plot) and then that was used to convert annual NPPag of individual trees obtained from Equations (1) or (2) to per plot annual NPPag for the years after road construction. As we did not have a baseline or previous vegetation survey data before road construction, we did not calculate the NPPag per plot for the period pre-road construction. The annual NPPag was converted to $C$ by assuming that $50 \%$ of the dry mass was C $[43,44]$.

\subsection{Statistical Analyses}

Generalized linear mixed effect models (GLMMs) with years and plots as random effects on both intercept and slope (Equation (3)) were performed separately for each tree/shrub species to see the effects of WT depth and BD on the annual tree ring growth.

$$
\mathrm{GR}=\mathrm{a}+\beta_{1}(\mathrm{WT})+\beta_{2}(\mathrm{BD})+\beta_{3}(\mathrm{WT} \times \mathrm{BD})+\mathrm{SE}
$$

where GR, or growth ring $(\mathrm{mm})$, is the annual radial growth of the sampled stem (black spruce, alder, birch, or willow) in 2016 and 2017, a is the intercept for the respective species, WT (cm) is the summer season average water table depth with respect to the surface, $\mathrm{BD}(\mathrm{cm})$ is the basal diameter of the corresponding stem, $\beta_{1}, \beta_{2}$ and $\beta_{3}$ are slopes of the respective variables, and $\mathrm{SE}$ is the standard error of the respective model.

GLMMs, year as a random variable with effect on both intercept and slope, were also performed to investigate the impact of the period relative to road construction and interaction of side of the road and the period relative to road construction as fixed factors on the tree ring growth rate in each study site (Equation (4)). Instead of measured tree ring width, we used ratios of tree ring width in downstream to reference and upstream to reference (ratio between road impacted areas and reference area tree rings) while performing GLMMs to compare before and after road construction.

$$
\mathrm{GRR}=\mathrm{a}+\beta_{1}(\mathrm{RD})+\beta_{2}(\text { side } \times \mathrm{BR})+\beta_{3}(\text { side } \times \mathrm{AR})+\mathrm{SE}
$$

where GRR, or growth ring ratio, is the ratio of tree ring width in downstream to reference and upstream to reference (ratio between road impacted areas and reference area tree rings), RD is period relative road construction (pre-road construction (BR, years 2010-2013 in fen and years 2008-2014 in bog) and post-road construction (AR, years 2014-2017 in fen and 2015-2017 in bog), a is the intercept for the respective species, $\beta_{1}, \beta_{2}$ and $\beta_{3}$ are slopes of the respective variables, and SE is the standard error of the respective model.

Moreover, GLMMs with plots and years as random variables with effects on both intercept and slope were performed separately for black spruce NPPag at the bog and combined NPPag of alder, birch and willow (tall shrubs) at the fen were performed to determine the impact of the road (side of and distance from the road) on the NPPag rate in each study site during the post-road construction period (Equation (5)).

$$
\mathrm{NPPag}=\mathrm{a}+\beta_{1}(\text { side })+\beta_{2}(\text { dist })+\beta_{3}(\text { side } \times \text { dist })+\mathrm{SE}
$$


where NPPag, aboveground annual net primary productivity, is the annual net primary productivity of black spruce or tall shrubs (combined alder, birch and willow) post-road construction (years 2014-2017 in fen and 2015-2017 in bog), a is the intercept for the respective species, side is the side of the road (upstream and downstream), dist is the perpendicular distance to the plots from the edge of the road $(2,6$ and $20 \mathrm{~m}), \beta_{1}, \beta_{2}$ and $\beta_{3}$ are slopes of the respective variables, and SE is the standard error of the respective model.

\section{Results}

In the cleared areas of the bog, areas where vegetation was cleared during road construction (i.e., upstream areas), we observed no tree growth except a few scattered regenerating seedlings and growth of sedges, horsetails and cattails. In contrast, in the cleared areas of the fen (i.e., downstream areas), we observed re-growth of some tall shrubs and complete ground cover of sedges, grasses and cattails. The mean tree density in the bog downstream of the road was $4.1 \pm 0.4 \mathrm{trees} / \mathrm{m}^{2}$ and in the upstream $0.6 \pm 0.3$ trees $/ \mathrm{m}^{2}$. At the bog, the average BD of trees was $3.9 \pm 0.2 \mathrm{~cm}$ and $3.2 \pm 0.2 \mathrm{~cm}$ in the downstream and upstream areas, respectively. At the fen, the mean shrub stem density in the areas downstream of the road was $2.0 \pm 0.4$ stems $/ \mathrm{m}^{2}$ and in the upstream areas, $6.7 \pm 0.8 \mathrm{stem} / \mathrm{m}^{2}$. The average $\mathrm{BD}$ in fen plots was $1.8 \pm 0.1 \mathrm{~cm}$ and $2.3 \pm 0.1 \mathrm{~cm}$ in the downstream and upstream areas, respectively.

GLMM results showed that generally, there was a difference in tree ring width between upstream and downstream areas (Table 2, Figure 2). However, most of these differences appear to be related to natural spatial variability in growth and not the presence of the road, with only a small amount of the variation in the tree ring width described by road-related factors. Post hoc comparisons showed that the ring width ratio (ratio of road impacted area to reference plots) of black spruce (Figure 2a), and willow (Figure 2d) was significantly higher in downstream areas compared to upstream areas during both pre- and post-road construction (Table 2). In contrast, the downstream ring width ratio of alder (Figure $2 b$ ) before road construction was significantly larger compared to the upstream ring width ratio before road construction (Table 2 ). The ring width ratio of birch (Figure $2 \mathrm{c}$ ) after road construction was significantly higher in the downstream areas post-road construction but not before road construction (Table 2 ).

In our study, black spruce had larger ring width ratios in the downstream areas than upstream areas irrespective of the road construction. However, there did appear to be divergent growth responses in upstream and downstream areas post-road construction, where ring width ratios consistently declined upstream and increased downstream (Figure 2a). Despite this pattern, there was no significant differences between upstream or downstream areas pre- and post-road construction $(0.03 \pm 0.07$, $t=0.481, p=0.965 ; 0.1 \pm 0.05, t=1.950, p=0.282$, respectively) in black spruce ring width ratios.

Similarly, willow had larger ring widths in the downstream areas compared to upstream areas during both pre- and post-road construction and there were no significant differences between upstream or downstream areas pre- and post-road construction $(0.03 \pm 0.05, t=0.621, p=0.925 ; 0.00 \pm 0.05$, $t=0.062, p=0.999)$. In contrast, the difference in ring width ratios of alder between upstream and downstream areas before road construction was not present after road construction as the upstream ring width ratio significantly increased post-road construction compared to pre-road construction $(0.3 \pm 0.1 ; t=4.72, p=0.01)$, ultimately resulting in a similar ring width ratio as the downstream area, which was similar to the ring width of reference areas. For birch, there was a pattern of decreasing ring widths in downstream and upstream areas. There were only significantly lower ring width ratios post-road construction in the upstream areas compared to upstream areas pre-road construction $(-0.2 \pm 0.04 ; t=-4.54, p<0.001)$, with non-significant differences in the downstream areas between pre-and post-road construction periods $(0.2 \pm 0.1 ; t=2.38, p=0.08)$. 
Table 2. Generalized linear mixed effect model results for annual radial growth with the year as a random factor and time of road construction (After road-AR and Before road-BR) and the interaction of time of road construction and side of the road as fixed factors (Upstream-U and Downstream-D) showing the effects on annual tree ring growth ${ }^{1}$ of black spruce in the bog, and alder, birch and willow in the fen before (BR) and after road (AR) construction, Carmon Creek, Peace River, Alberta, Canada.

\begin{tabular}{|c|c|c|c|c|}
\hline \multirow{2}{*}{ Effects } & \multicolumn{4}{|c|}{ Black Spruce $\left(R^{2}=0.05, F_{(10,1464)}=1905.61, p<0.0001\right)$} \\
\hline & Estimates ${ }^{2}$ & Standard Error & $t$-Values & $p$ Values \\
\hline Intercept & 0.894 & 0.044 & 21.684 & 0.000 \\
\hline AR-BR & -0.096 & 0.049 & -1.949 & 0.087 \\
\hline D (AR)-U (AR) & -0.178 & 0.055 & -3.264 & 0.001 \\
\hline \multirow[t]{2}{*}{ D (BR)-U (BR) } & -0.113 & 0.036 & -3.144 & 0.002 \\
\hline & \multicolumn{4}{|c|}{ Alder $\left(R^{2}=0.09, F_{(8,619)}=2062.94, p<0.0001\right)$} \\
\hline Intercept & 1.013 & 0.039 & 26.375 & 0.000 \\
\hline AR-BR & -0.001 & 0.077 & -0.001 & 0.947 \\
\hline $\mathrm{D}(\mathrm{AR})-\mathrm{U}(\mathrm{AR})$ & 0.054 & 0.051 & 1.059 & 0.389 \\
\hline \multirow[t]{2}{*}{ D (BR)-U (BR) } & -0.209 & 0.056 & -3.193 & 0.002 \\
\hline & \multicolumn{4}{|c|}{ Birch $\left(R^{2}=0.10, F_{(8,521)}=2001.58, p<0.0001\right)$} \\
\hline Intercept & 0.916 & 0.058 & 17.451 & 0.000 \\
\hline AR-BR & 0.180 & 0.077 & 2.961 & 0.017 \\
\hline D (AR)-U (AR) & -0.137 & 0.061 & -2.114 & 0.030 \\
\hline \multirow[t]{2}{*}{$\mathrm{D}(\mathrm{BR})-\mathrm{U}(\mathrm{BR})$} & -0.093 & 0.069 & -1.239 & 0.173 \\
\hline & \multicolumn{4}{|c|}{ Willow $\left(R^{2}=0.09, F_{(8,641)}=927.91, p<0.0001\right)$} \\
\hline Intercept & 0.896 & 0.043 & 21.496 & 0.000 \\
\hline AR-BR & -0.092 & 0.062 & -1.950 & 0.091 \\
\hline D (AR)-U (AR) & -0.178 & 0.052 & -3.033 & 0.001 \\
\hline D (BR)-U (BR) & -0.113 & 0.041 & -3.414 & 0.001 \\
\hline
\end{tabular}

${ }^{1}$ Tree ring growth values used in the analyses are ratios of road impacted area $(\mathrm{U}$ or $\mathrm{D})$ ring widths to the reference area tree ring widths of respective species. ${ }^{2}$ Bold emphasized estimate values indicate the significant effects $(p<0.05)$. A negative value for AR-BR means lower tree radial growth before road construction and, if estimate for $\mathrm{D}(\mathrm{AR})-\mathrm{U}(\mathrm{AR})$, shows a negative value, it means lower tree radial growth in upstream than in the downstream area.

GLMM analyses indicated that the interacting effect of WT and BD was significant in predicting annual tree ring growth of black spruce (Table 3), suggesting the shift in WT has different effects on growth depending on the size of the tree. In general, a shallower WT resulted in less annual radial growth, but this effect was most pronounced for trees with larger BD. BD was a significant predictor of the annual growth of alder, birch and willow (Table 3) with higher BD shrubs having larger ring widths.

At the bog, black spruce NPPag was greatly reduced with time post-road construction on the upstream side of the road, while at the fen, NPPag had little response to the road. The GLMM results of NPPag after road construction showed significant variation between upstream and downstream areas of the road in both bog $\left(R^{2}=0.23, p<0.0001, F_{(3,126)}=53.97\right)$ and fen $\left(R^{2}=0.10, p<0.0001\right.$, $F_{(4,156)}=155.65$; Table 4, Figure 3). Post hoc comparison showed that the bog had a significantly higher NPPag rate in the downstream areas compared to upstream areas $(t=5.21, p<0.0001)$, which was significantly lower than the reference area NPPag rate $(t=3.26, p<0.002$; Table 4 ,). In contrast, at the fen, the NPPag rate in the upstream areas was significantly higher compared to downstream areas $(t=2.64, p=0.07)$, which was again significantly less than reference areas $(t=2.41, p=0.044$; Table 4$)$. 


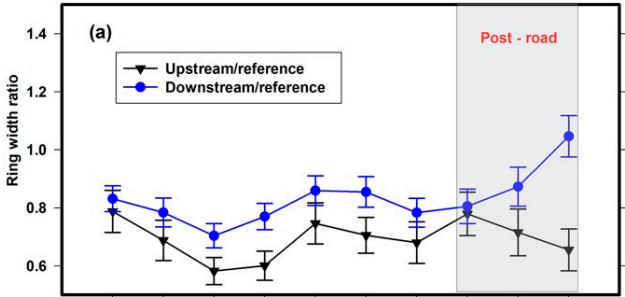

$2008 \quad 2009201020112012 \quad 2013 \quad 2014 \quad 2015 \quad 2016 \quad 2017$

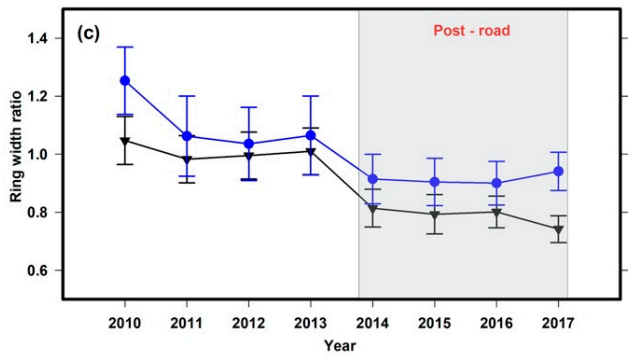

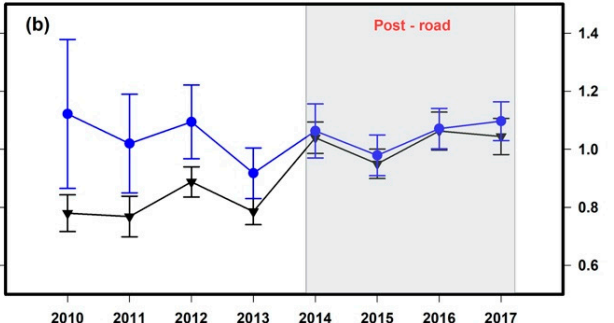

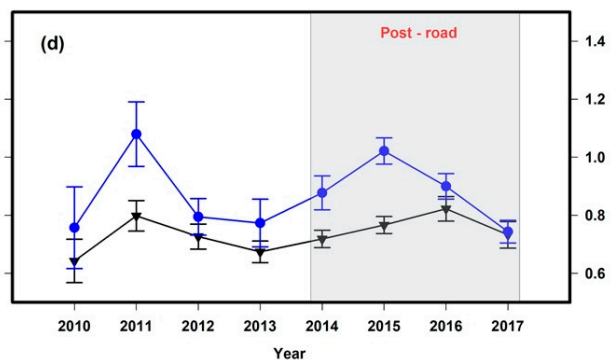

Figure 2. Annual growth ring width ratios of (a) black spruce, (b) alder, (c) birch and (d) willow from 2008 to 2017 in the bog and 2010 to 2017 in the fen sites of Carmon Creek, Peace River, Alberta. Years 2015-2017 in the bog and Years 2014-2017 in the fen represent the period post-road construction. Symbols and error bars represent the mean and standard errors of annual growth ring width ratios for the respective year. Upstream/reference-ratio of upstream and reference site ring widths and downstream/reference-ratio of downstream and reference site ring widths.

Table 3. Generalized linear mixed effect models, years (2016 and 2017) and plots as random factors, results showing the effects of basal diameter (BD) and depth to water table with respect to surface (WT) on annual tree ring growth ${ }^{1}$ of black spruce in the bog, and alder, birch and willow in the fen, Carmon Creek, Peace River, Alberta, Canada.

\begin{tabular}{|c|c|c|c|c|}
\hline \multirow{2}{*}{ Effects } & \multicolumn{4}{|c|}{ Black Spruce $\left(R^{2}=0.20, F_{(2,296)}=63.20, p<0.0001\right)$} \\
\hline & Estimates $^{2}$ & Standard Error & $t$-Values & $p$ Values \\
\hline Intercept & 0.185 & 0.053 & 3.490 & 0.001 \\
\hline WT & -0.004 & 0.002 & -2.283 & 0.027 \\
\hline $\mathrm{BD}$ & 0.024 & 0.009 & 2.721 & 0.007 \\
\hline \multirow[t]{2}{*}{$\mathrm{WT} \times \mathrm{BD}$} & 0.001 & 0.0003 & 2.590 & 0.010 \\
\hline & \multicolumn{4}{|c|}{ Alder $\left(R^{2}=0.41, F_{(2,226)}=372.52, p<0.0001\right)$} \\
\hline Intercept & 1.408 & 0.138 & 10.209 & 0.000 \\
\hline WT & 0.021 & 0.013 & 1.662 & 0.1023 \\
\hline $\mathrm{BD}$ & 0.187 & 0.045 & 4.154 & 0.0001 \\
\hline \multirow[t]{2}{*}{$\mathrm{WT} \times \mathrm{BD}$} & -0.008 & 0.005 & -1.751 & 0.0817 \\
\hline & \multicolumn{4}{|c|}{$\operatorname{Birch}\left(R^{2}=0.37, F_{(2,161)}=112.74, p<0.0001\right)$} \\
\hline Intercept & 1.007 & 0.199 & 5.064 & 0.000 \\
\hline WT & -0.034 & 0.013 & -2.588 & 0.011 \\
\hline $\mathrm{BD}$ & 0.173 & 0.030 & 5.798 & 0.000 \\
\hline \multirow[t]{2}{*}{$\mathrm{WT} \times \mathrm{BD}$} & 0.004 & 0.003 & 1.399 & 0.164 \\
\hline & \multicolumn{4}{|c|}{ Willow $\left(R^{2}=0.20, \mathrm{~F}_{(1,239)}=1551.31, p<0.0001\right)$} \\
\hline Intercept & 0.967 & 0.087 & 11.078 & 0.000 \\
\hline WT & 0.009 & 0.007 & 1.284 & 0.201 \\
\hline $\mathrm{BD}$ & 0.179 & 0.051 & 3.516 & 0.001 \\
\hline $\mathrm{WT} \times \mathrm{BD}$ & -0.002 & 0.004 & -0.575 & 0.566 \\
\hline
\end{tabular}

${ }^{1}$ Tree ring growth values used in the analyses area ratio or road impacted area (U or D) ring widths to the reference area tree ring widths of respective species. ${ }^{2}$ Bold emphasized estimate values indicate the significant effects $(p<0.05)$. 
Table 4. Annual aboveground tree and shrub net primary productivity (NPPag) in the upstream, downstream sides (Side) of the road at the plots located at 2,6 and $20 \mathrm{~m}$ perpendicular distance from the road edge and reference areas at bog and fen site during years post-road construction, Carmon Creek, Peace River, Alberta.

\begin{tabular}{|c|c|c|c|}
\hline \multirow[t]{2}{*}{ Side of the Road } & \multirow[t]{2}{*}{ Distance to Plots (m) } & \multicolumn{2}{|c|}{$\begin{array}{c}\text { NPPag } \\
\text { Mean } \pm \text { SE }\left(\mathrm{g}-\mathrm{C} / \mathrm{m}^{2}\right)^{1}\end{array}$} \\
\hline & & Bog & Fen \\
\hline Downstream & 2 & $164.7 \pm 30.1^{a}$ & $29.4 \pm 3.5^{a}$ \\
\hline Downstream & 6 & $51.9 \pm 5.8^{\mathrm{b}}$ & $56.6 \pm 14.1^{b}$ \\
\hline Downstream & 20 & $58.2 \pm 6.5^{b}$ & $187.4 \pm 27.4^{\mathrm{C}}$ \\
\hline Downstream & mean $\pm \mathrm{SE}$ & $91.6 \pm 12.6^{d}$ & $91.8 \pm 14.7^{\mathrm{d}}$ \\
\hline Upstream & 2 & $0.0 \pm 0.0^{c}$ & $110.2 \pm 19.2$ \\
\hline Upstream & 6 & $0.0 \pm 0.0^{c}$ & $154.3 \pm 20.8^{c}$ \\
\hline Upstream & 20 & $58.4 \pm 11.8^{b}$ & $176.6 \pm 33.8^{c}$ \\
\hline Upstream & mean $\pm \mathrm{SE}$ & $19.6 \pm 11.3^{\mathrm{e}}$ & $147.9 \pm 14.7^{\mathrm{e}}$ \\
\hline \multicolumn{2}{|c|}{ Reference areas } & $101.3 \pm 19.4^{\mathrm{d}}$ & $182.7 \pm 41.1^{\mathrm{f}}$ \\
\hline
\end{tabular}

${ }^{1}$ Different superscript letters in a column represent the significantly different mean NPPag between groups (e.g., Downstream vs. Upstream; Downstream $2 \mathrm{~m}$ vs. Downstream $6 \mathrm{~m}$, etc.) within the bog or fen $(p<0.05)$.
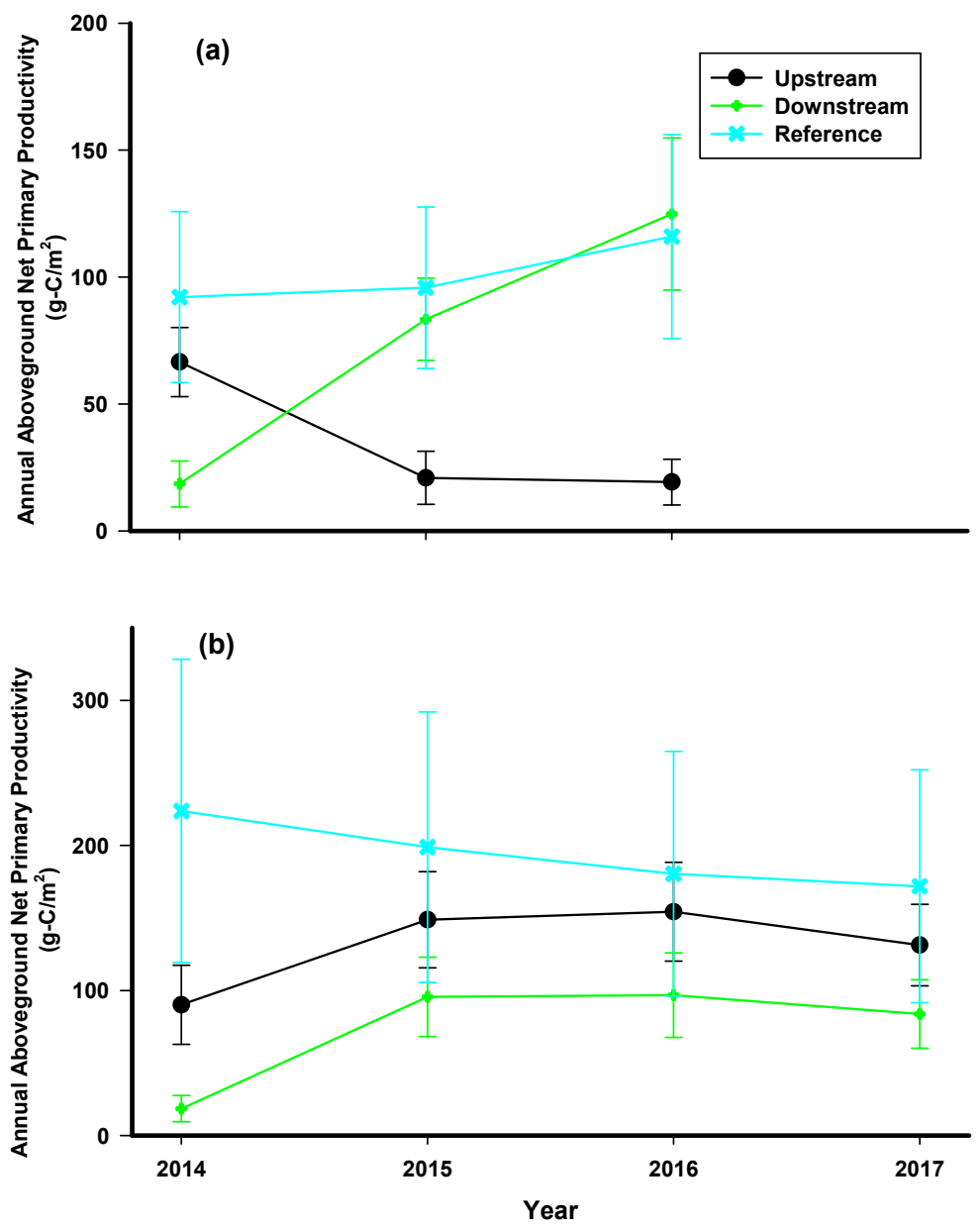

Figure 3. Annual aboveground tree and shrub net primary productivity (NPPag) in upstream and downstream areas of the road and reference areas at (a) bog and (b) fen sites during years post-road construction, Carmon Creek, Peace River, Alberta. Symbols and error bars represent the mean and standard errors of NPPag of the respective years. 
The greatest impact of the road in terms of NPPag was observed closest to the road in both bog and fen. No NPPag was present in the tree cleared areas of the bog (plots at 2 and $6 \mathrm{~m}$ ) in the upstream areas (Table 4), whereas the $2 \mathrm{~m}$ plots in the downstream areas of the bog had significantly higher NPPag than any area of the bog $(t=4.48, p<0.0001$; Table 4$)$. There was a similar rate of NPPag in the downstream 6 and $20 \mathrm{~m}$, and upstream $20 \mathrm{~m}$ areas in the bog (Table 4). However, in the fen, though no plot was devoid of NPPag of tall shrubs, the vegetation cleared plots (downstream 2 and $6 \mathrm{~m}$ plots) had significantly lower NPPag compared to other areas of the fen $(t=4.48, p<0.001 ; t=3.84, p<0.001$, respectively; Table 4). NPPag in areas around $20 \mathrm{~m}$ from the road in both sides in the fen had a similar rate $(t=0.33, p<0.99)$.

\section{Discussion}

In this study of the impact assessment of roads in boreal wooded and shrubby peatlands, we found that the fragmented parts of the peatlands had a significant difference in the growth of trees and tall shrubs with a substantial reduction of NPPag after the road construction. Both NPPag rate and tree density post-road construction were substantially reduced in the upstream areas of the bog, linked to both hydrologic changes and vegetation clearing. The overall annual growth post-road construction within $20 \mathrm{~m}$ of the road decreased substantially compared to the reference areas in both study sites. At the fen, the downstream areas of the site showed a significant reduction in NPPag reflecting the effect of the vegetation removal during road construction. The impact of roads on NPPag was greatest at the road-adjacent areas (upstream of the bog and downstream of the fen at plots at 2 and $6 \mathrm{~m}$ from the road edge). As our plots were distributed in a relatively small area $\left(<3000 \mathrm{~m}^{2}\right)$, the effect of climatic factors is expected to be similar in all sample plots but may have contributed to interannual variability in annual radial growth. We also observed large spatial variability in annual growth of all species where growth often varied between upstream and downstream areas prior to road construction (Figure 2). To account for this, we compared annual radial growth and NPPag in road affected areas to reference plots. There remains some uncertainty around the assignment of ring width values to specific years due to difficulties with cross-dating samples. While this should be considered when interpreting our results, we are more interested in the multi-year signals which may be less influenced by the potential misassignment of individual years.

The hydrologic impact of road construction was not consistent at our two study sites, largely linked to the orientation of the road relative to local slope [3]. Little change in WT position near the road was observed at the fen, while upstream areas of the bog experienced inundation, but downstream areas had deeper WT [3]. Therefore, any changes in the growth pattern at the bog are likely linked with the WT variation induced by road construction. Some studies report that shallower WT position may reduce the growth of black spruce in boreal peatlands, e.g., [12-14,17], while others observed that the impact of WT position on black spruce growth may not be as significant due to the long-term control by air temperature and precipitation $[15,16]$, and microtopography of the peatlands, e.g., $[17,19,20,45]$. In our study, there was a significant interaction of WT and BD for explaining variation in annual tree ring growth of black spruce indicating that different size trees are impacted differently by the change in the WT position. Peatland trees have concentrated fine roots in the hummocks and nearby to the higher tree density areas, e.g., [19,40], which prevents trees from completely flooding under natural topography, hence may negate the impact of WT position. This indicated the possibility of having larger ring widths in the upstream areas of the bog for trees growing on hummocks. However, in the downstream areas of the bog, relatively deeper WT position favored the thicker growth rings in trees with larger BD.

Across both study sites, we observed that differences in the tree ring width ratios between and within downstream and upstream areas in relation to the road construction varied with the tree species. Black spruce and willow had larger ring width ratios in the downstream areas than upstream areas, irrespective of the road construction, but there were significant differences in pre-road construction and post-road construction in alder and birch. In contrast to black spruce, studies are limited discussing 
the hydrological niche of birch, willow and alder. A comprehensive study looking into the long-term drainage impact in boreal fens found growth enhancement of trees resulting in increased NPPag when WT was lowered by more than $30 \mathrm{~cm}$ for minimum of two decades in the boreal region though the impact on shrubs was minimal in terms of the NPP rate [23]. However, in our study, there was no evidence of change in annual radial growth in the fen suggesting that all tall shrubs in the fen were not clearly impacted by the road construction. Primarily, this could be linked with the limited alteration in WT between upstream and downstream areas in the fen. Moreover, due to the limited hydrological impact at the fen, our data covers a limited range of WT variation [3] and, therefore, we may not have captured the full spectrum of conditions present at road-impacted fen sites. We did observe a positive relationship of $\mathrm{BD}$ and tree ring growth in the fen that is likely because of a relatively young stand age in the fen. Tree girth in our study area was relatively small with the average BD in the bog and fen $3.5 \pm 0.2 \mathrm{~cm}$ and $2.1 \pm 0.1 \mathrm{~cm}$, respectively. Furthermore, as discussed above, most trees surviving in the fen have fine roots in the hummocks and thus, can maintain growth despite some flooding. Trees growing in areas more favorable to them, i.e., deeper WT position, and hummocks, are better positioned to have enhanced growth and hence have both larger tree rings and BD. Studies conducted in peatlands subject to drainage for decades [17,46], and disturbed by winter roads [47,48], have shown that the lower WT position in the long-term favors the growth of tall shrubs and trees in the expense of bryophyte and small shrub biomass.

In the bog, a significant loss of NPPag was observed in the upstream areas and though the NPPag in the downstream areas, mainly at $2 \mathrm{~m}$ from the road, increased over time it did not balance upstream declines, leading to the net loss of NPPag annually post-road construction. This is mainly due to two reasons: the upstream areas of the bog that were cleared up to $18 \mathrm{~m}$ from the road for increased visibility and the shallower WT position in the upstream areas with persistent flooding in some areas that reduced the growth of black spruce if not dead already. At the bog, the construction of the road caused flooded conditions on the upstream areas of the road by limiting the flow of water as the flow was perpendicular to the road orientation [3]. The tree mortality as a result of inundation due to the water flow blockage has also been observed in other boreal peatlands [30], boreal forest and boreal-tundra boundary ecosystems $[49,50]$. The results are consistent with these findings with flooding conditions resulting in tree mortality by which an estimated rate of $8.8 \pm 1.9 \mathrm{kgC} / \mathrm{m}^{2} \mathrm{in}$ terms of aboveground tree biomass was lost after road construction in the bog. Consequently, most of the trees up to $15 \mathrm{~m}$ away from the road edge were dead resulting in reduced NPPag on the upstream areas of the road. The significantly higher NPPag observed in the downstream $2 \mathrm{~m}$ areas at the bog may be linked with the deeper WT position, higher tree density, and added nutrients from road fill material leaching (which was not measured in this study).

Combining the effects of tree clearing and hydrology induced shifts in growth, the overall annual growth within $20 \mathrm{~m}$ of the road decreased substantially compared to the reference areas. Significantly lower NPPag (averaged downstream and upstream) in the bog (difference: $40.9 \pm 15.8 \mathrm{gC} / \mathrm{m}^{2} ; t=6.74$, $p<0.001$ ) and fen (difference: $63.5 \pm 18.4 \mathrm{gC} / \mathrm{m}^{2} ; t=3.42, p=0.04$ ) near the road areas compared to reference areas shows tremendous loss of carbon sink potential of trees and shrubs post-road construction across these peatlands. Moreover, an irreversible loss of carbon due to the tree removal under the direct footprint of the road, and on the side of the road in both bog and fen, tree mortality resulting from inundation in the upstream areas of the bog, and overall enhanced hydrolytic enzyme activities linking to increased peat decomposition [36] may change these peatlands from long-term carbon sinks to sources of carbon for at least the initial few years after road construction. Further studies are recommended to explore understory and below-ground carbon storage associated with roads having a long history of water impounding. In addition, though not measured in this study, differences in soil nutrients between upstream and downstream areas of the fragmented peatland resulting from the source of water flow may impact the tree growth in peatlands [51]. 


\section{Conclusions}

When roads pass through peatlands, the annual growth of the trees and tall shrubs is impacted in two ways. First, the vegetation clearance mostly ceased tree and tall shrub productivity in cleared areas. Second, the areas with inundation saw rapid tree mortality and a substantially lower annual growth, whereas, trees and tall shrubs in relatively dry downstream areas benefited from the road construction at least in the initial years following road construction. However, the difference observed between downstream and upstream tree NPPag provides strong evidence that when roads are constructed that impede water and alter WT positions there will be a substantial reduction in tree growth in the upstream areas. We recommend studies looking across more peatlands/roads to evaluate long-term impacts, highlighting tree rings as a valuable record of changing conditions even when hydrologic data is not available.

Supplementary Materials: The following is available online at http://www.mdpi.com/1999-4907/11/5/594/s1, Table S1: Chronology data for each site (bog/fen) and species (black spruce/alder/birch/willow) with sample depth (referring to the number of samples per chronology), mean ring size (in $\mathrm{mm}$ ) and the inter-series correlation value (a measure of how synchronous ring measurement are between years). These chronologies run from 2008-2017.

Author Contributions: S.S., Y.B., M.S. contributed to the conceptualization and methodology of the field sampling. S.S. and Y.B. processed samples in the laboratory; S.S. and Y.B. curated data; A.J.T. and M.S. validated data; S.S. wrote the original draft; S.S., Y.B., A.J.T. and M.S. reviewed and edited the manuscript; M.S. supervised, acquisitioned and managed the project. All authors have read and agreed to the published version of the manuscript.

Funding: This research was funded by Shell Canada, Emission Reduction Alberta (ERA; grant number B140020) and Canadian Natural Resources Limited (CNRL).

Acknowledgments: We thank Shell Canada and CNRL for providing site access. We are highly grateful to NAIT Boreal Research Institute for logistical support and site set-up. We thank Jorden Fanson and Michael Jean Wrubleski for helping in the field to collect samples. We acknowledge that the study sites are located on Treaty 8 territory, traditional lands of Woodland Cree, Mikisew Cree, and Duncan First Nations.

Conflicts of Interest: Authors declare no conflict of interest. The funders had no role in the design of the study; in the collection, analyses, or interpretation of data; in the writing of the manuscript, or in the decision to publish the results.

\section{References}

1. Vitt, D.; Halsey, L.; Bauer, I.; Campbell, C. Spatial and temporal trends in carbon storage of peatlands of continental western Canada through the Holocene. Can. J. Earth Sci. 2000, 37, 683-693. [CrossRef]

2. Page, S.E.; Reiley, J.O.; Banks, C.J. Global and regional importance of the tropical peatland carbon pool. Glob. Chang. Biol. 2011, 17, 798-818. [CrossRef]

3. Saraswati, S.; Petrone, R.M.; Mustafiz, R.; McDermid, G.J.; Xu, B.; Strack, M. Hydrological effects of resource-access road crossings on boreal forested peatlands. J. Hydrol. 2020, 584, 124748. [CrossRef]

4. Alm, J.; Schulman, L.; Walden, J.; Nykanen, H.; Martikainen, P.J.; Silvola, J. Carbon balance of a boreal bog during a year with an exceptionally dry summer. Ecology 1999, 80, 161-174. [CrossRef]

5. Petrone, R.M.; Solondz, D.S.; Macrae, M.L.; Gignac, D.; Devito, K.J. Microtopographical and canopy cover controls on moss carbon dioxide exchange in a western Boreal Plain peatland. Ecohydrology 2011, 4, 115-129. [CrossRef]

6. Weltzin, J.F.; Pastor, J.; Harth, C.; Bridgham, S.D.; Updegraff, K.; Chapin, C.T. Response of Bog and Fen Plant Communities to Warming and Water-Table Manipulations. Ecology 2000, 81, 3464-3478. [CrossRef]

7. Mitsch, W.J.; Gosselink, J.G. Wetlands, 5th ed.; John Wiley \& Sons, Inc.: Hoboken, NJ, USA, 2015; ISBN 9781118676820.

8. Laiho, R. Decomposition in peatlands: Reconciling seemingly contrasting results on the impacts of lowered water levels. Soil Biol. Biochem. 2006, 38, 2011-2024. [CrossRef]

9. Clymo, R.S.; Pearce, D.M.E.; Conrad, R. Methane and Carbon Dioxide Production in, Transport through, and Efflux from a Peatland. Philos. Trans. R. Soc. 1995, 351, 249-259.

10. Gorham, E. Northern peatlands: Role in the carbon cycle and probably responses to climate warming. Ecol. Appl. 1991, 1, 182-195. [CrossRef] 
11. Freeman, C.; Ostle, N.; Kang, H. An enzymic "latch" on a global carbon store. Nature 2001, 409, 149. [CrossRef]

12. Keim, R.F.; Amos, J.B. Dendrochronological analysis of baldcypress (Taxodium distichum) responses to climate and contrasting flood regimes. Can. J. For. Res. 2012, 42, 423-436. [CrossRef]

13. Tardif, J.; Bergeron, Y. Comparative dendroclimatological analysis of two black ash and two white cedar populations from contrasting sites in the Lake Duparquet region, northwestern Quebec. Can. J. For. Res. 1997, 27, 108-116. [CrossRef]

14. Lieffers, V.J.; Rothwell, R.L. Rooting of peatland black spruce and tamarack in relation to depth of water table. Can. J. Bot. 1987, 65, 817-821. [CrossRef]

15. Dymond, S.F.; D'Amato, A.W.; Kolka, R.K.; Bolstad, P.V.; Sebestyen, S.D.; Gill, K.; Curzon, M.T. Climatic controls on peatland black spruce growth in relation to water table variation and precipitation. Ecohydrology 2019, 12, e2137. [CrossRef]

16. Dang, Q.L.; Lieffers, V.J. Climate and annual ring growth of black spruce in some Alberta peatlands. Can. J. Bot. 1989, 67, 1885-1889. [CrossRef]

17. Munir, T.M.; Perkins, M.; Kaing, E.; Strack, M. Carbon dioxide flux and net primary production of a boreal treed bog: Responses to warming and water-table-lowering simulations of climate change. Biogeosciences 2015, 12, 1091-1111. [CrossRef]

18. Blodau, C.; Moore, T.R. Experimental response of peatland carbon dynamics to a water table fluctuation. Aquat. Sci-Res. Across Boundaries 2003, 65, 47-62. [CrossRef]

19. Charman, D. Peatlands and Environmental Change.; John Wiley \& Sons Ltd: Chichester, UK, 2002; ISBN 0470844108.

20. Iversen, C.M.; Childs, J.; Norby, R.J.; Ontl, T.A.; Kolka, R.K.; Brice, D.J.; McFarlane, K.J.; Hanson, P.J. Fine-root growth in a forested bog is seasonally dynamic, but shallowly distributed in nutrient-poor peat. Plant Soil 2018, 424, 123-143. [CrossRef]

21. Hsueh, Y.H.; Chambers, J.L.; Krauss, K.W.; Allen, S.T.; Keim, R.F. Hydrologic exchanges and baldcypress water use on deltaic hummocks, Louisiana, USA. Ecohydrology 2016, 9, 1452-1463. [CrossRef]

22. Strack, M.; Waller, M.F.; Waddington, J.M. Sedge Succession and Peatland Methane Dynamics: A Potential Feedback to Climate Change. Ecosystems 2006, 9, 278-287. [CrossRef]

23. Miller, C.A.; Benscoter, B.W.; Turetsky, M.R. The effect of long-term drying associated with experimental drainage and road construction on vegetation composition and productivity in boreal fens. Wetl. Ecol. Manag. 2015, 23, 845-854. [CrossRef]

24. Plach, J.M.; Wood, M.E.; Macrae, M.L.; Osko, T.J.; Petrone, R.M. Effect of a semi-permanent road on N, P, and CO2 dynamics in a poor fen on the Western Boreal Plain, Canada. Ecohydrology 2017, 10, e1874. [CrossRef]

25. Wood, M.E.; Macrae, M.L.; Strack, M.; Price, J.S.; Osko, T.J.; Petrone, R.M. Spatial variation in nutrient dynamics among five different peatland types in the Alberta oil sands region. Ecohydrology 2016, 9, 688-699. [CrossRef]

26. Caners, R.T.; Lieffers, V.J. Divergent Pathways of Successional Recovery for In Situ Oil Sands Exploration Drilling Pads on Wooded Moderate-Rich Fens in Alberta, Canada. Restor. Ecol. 2014, 22, 657-667. [CrossRef]

27. Vitt, D.H.; Wieder, R.K.; Xu, B.; Kaskie, M.; Koropchak, S. Peatland establishment on mineral soils: Effects of water level, amendments, and species after two growing seasons. Ecol. Eng. 2011, 37, 354-363. [CrossRef]

28. Strack, M.; Hayne, S.; Lovitt, J.; McDermid, G.J.; Rahman, M.M.; Saraswati, S.; Xu, B. Petroleum exploration increases methane emissions from northern peatlands. Nat. Commun. 2019, 10, 2804. [CrossRef]

29. Graf, M.D. Literature Review on the Restoration of Alberta's Boreal Wetlands: Affected by Oil, Gas and in Situ Oil Sands Development; Ducks Unlimited Canada: Edmonton, AB, Canada, 2009.

30. Bocking, E.; Cooper, D.J.; Price, J. Using tree ring analysis to determine impacts of a road on a boreal peatland. For. Ecol. Manage. 2017, 404, 24-30. [CrossRef]

31. Rooney, R.C.; Bayley, S.E.; Schindler, D.W. Oil sands mining and reclamation cause massive loss of peatland and stored carbon. Proc. Natl. Acad. Sci. USA 2012, 109, 4933-4937. [CrossRef]

32. Pasher, J.; Seed, E.; Duffe, J. Development of boreal ecosystem anthropogenic disturbance layers for Canada based on 2008 to 2010 Landsat imagery. Can. J. Remote Sens. 2013, 39, 42-58. [CrossRef]

33. Partington, M.; Gillies, C.; Gingras, B.; Smith, C.; Morissette, J. Resource Roads and Wetlands: A Guide for Planning, Construction and Maintenance; FPInnovations: Quebec City, QC, Canada, 2016; ISBN 978-0-86488-573-9. 
34. Willier, C. Changes in Peatland Plant Communitity Composition and Stand Structure Due to Road Induced Flooding and Desiccation. Mater's Thesis, University of Alberta, Edmonton, AB, Canada, 2017.

35. Environment and Climate Change Canada Daily Data Report for May 2014-Climate-Environment and Climate Change Canada. Available online: http://climate.weather.gc.ca/climate_data/daily_data_e.html?StationID= $52258 \&$ timeframe $=2 \&$ Start Year $=1840 \&$ End Year $=2018 \&$ Day $=11 \&$ Year $=2014 \&$ Month $=5 \# \quad$ (accessed on 12 September 2018).

36. Saraswati, S.; Parsons, C.T.; Strack, M. Access roads impact enzyme activities in boreal forested peatlands. Sci. Total Environ. 2019, 651, 1405-1415. [CrossRef]

37. R Core Team R: A Language and Environment for Statistical Computing 2019. Available online: https://www.r-project.org/ (accessed on 16 December 2019).

38. Bunn, A.; Korpela, M.; Biondi, F.; Campelo, F.; M'erian, P.; Qeadan, F.; Zang, C. dplR: Dendrochronology Program Library in R. R package version 1.7.1 2020. Available online: https://github.com/AndyBunn/dplR (accessed on 10 March 2020).

39. Bunn, A.G. Statistical and visual crossdating in R using the dplR library. Dendrochronologia 2010, 28, 251-258. [CrossRef]

40. Bunn, A.G. A dendrochronology program library in R (dplR). Dendrochronologia 2008, 26, 115-124. [CrossRef]

41. Bond-Lamberty, B.; Wang, C.; Gower, S.T. Aboveground and belowground biomass and sapwood area allometric equations for six boreal tree species of northern Manitoba. Can. J. For. Res. 2002, 32, 1441-1450. [CrossRef]

42. He, A.; McDermid, G.J.; Rahman, M.M.; Strack, M.; Saraswati, S.; Xu, B. Developing allometric equations for estimating shrub biomass in a boreal fen. Forests 2018, 9, 569. [CrossRef]

43. IPCC. 2006 IPCC Guidelines for National Greenhouse Gas Inventories; Eggleston, S., Buendia, L., Miwa, K., Ngara, T., Tanabe, K., Eds.; IGES: Hayama, Japan, 2006; ISBN 4-88788-032-4.

44. Somogyi, Z.; Cienciala, E.; Mäkipää, R.; Muukkonen, P.; Lehtonen, A.; Weiss, P. Indirect methods of large-scale forest biomass estimation. Eur. J. For. Res. 2007, 126, 197-207. [CrossRef]

45. Ontl, T.; Iversen, C. SPRUCE S1 Bog Areal Coverage of Hummock and Hollow Microtopography Assessed Along Three Transects in the S1 Bog; U.S. Department of Energy: Oak Ridge, TN, USA, 2017.

46. Murphy, M.; Laiho, R.; Moore, T.R. Effects of water table drawdown on root production and aboveground biomass in a boreal Bog. Ecosystems 2009, 12, 1268-1282. [CrossRef]

47. Campbell, D.; Bergeron, J. Natural Revegetation of Winter Roads on Peatlands in the Hudson Bay Lowland, Canada. Arctic, Antarct. Alp. Res. 2012, 44, 155-163. [CrossRef]

48. Strack, M.; Softa, D.; Bird, M.; Xu, B. Impact of winter roads on boreal peatland carbon exchange. Glob. Chang. Biol. 2018, 24, e201-e212. [CrossRef]

49. Tei, S.; Morozumi, T.; Nagai, S.; Takano, S.; Sugimoto, A.; Shingubara, R.; Fan, R.; Fedorov, A.; Gavrilyeva, T.; Tananaev, N.; et al. An extreme flood caused by a heavy snowfall over the Indigirka River basin in Northeastern Siberia. Hydrol. Process. 2020, 34, 522-537. [CrossRef]

50. Tei, S.; Sugimoto, A.; Yonenobu, H.; Kotani, A.; Maximov, T.C. Effects of extreme drought and wet events for tree mortality: Insights from tree-ring width and carbon isotope ratio in a Siberian larch forest. Ecohydrology 2019, 12, e2143. [CrossRef]

51. Choi, W.-J.; Chang, S.X.; Bhatti, J.S. Drainage affects tree growth and C and N dynamics in a minerotrophic peatland. Ecology 2007, 88, 443-453. [CrossRef]

(C) 2020 by the authors. Licensee MDPI, Basel, Switzerland. This article is an open access article distributed under the terms and conditions of the Creative Commons Attribution (CC BY) license (http://creativecommons.org/licenses/by/4.0/). 